Article

\title{
Spatial-Temporal Land Loss Modeling and Simulation in a Vulnerable Coast: A Case Study in Coastal Louisiana
}

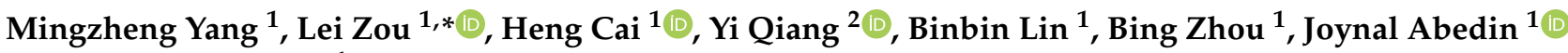 \\ and Debayan Mandal ${ }^{1}$ \\ 1 Department of Geography, Texas A\&M University, College Station, TX 77843, USA; \\ ymz2020@tamu.edu (M.Y.); hengcai@tamu.edu (H.C.); bb2020@tamu.edu (B.L.); spgbarrett@tamu.edu (B.Z.); \\ j.abedin@tamu.edu (J.A.); rohan_debayan@tamu.edu (D.M.) \\ 2 School of Geosciences, University of South Florida, Tampa, FL 33620, USA; qiangy@usf.edu \\ * Correspondence: lzou@tamu.edu; Tel.: +1-(979)-458-1803
}

\section{check for}

updates

Citation: Yang, M.; Zou, L.; Cai, H.; Qiang, Y.; Lin, B.; Zhou, B.; Abedin, J.; Mandal, D. Spatial-Temporal Land Loss Modeling and Simulation in a Vulnerable Coast: A Case Study in Coastal Louisiana. Remote Sens. 2022, 14, 896. https://doi.org/10.3390/ rs14040896

Academic Editors:

Andrea Ciampalini and Bruce

D. Chapman

Received: 16 November 2021

Accepted: 4 February 2022

Published: 13 February 2022

Publisher's Note: MDPI stays neutral with regard to jurisdictional claims in published maps and institutional affiliations.

Copyright: (C) 2022 by the authors. Licensee MDPI, Basel, Switzerland. This article is an open access article distributed under the terms and conditions of the Creative Commons Attribution (CC BY) license (https:// creativecommons.org/licenses/by/ $4.0 /)$.

\begin{abstract}
Coastal areas serve as a vital interface between the land and sea or ocean and host about $40 \%$ of the world's population, providing significant social, economic, and ecological functions. Meanwhile, the sea-level rise caused by climate change, along with coastal erosion and accretion, alters coastal landscapes profoundly, threatening coastal sustainability. For instance, the Mississippi River Delta in Louisiana is one of the most vulnerable coastal areas. It faces severe long-term land loss that has disrupted the regional ecosystem balance during the past few decades. There is an urgent need to understand the land loss mechanism in coastal Louisiana and identify areas prone to land loss in the future. This study modeled the current and predicted the future land loss and identified natural-human variables in the Louisiana Coastal Zone (LCZ) using remote sensing and machine-learning approaches. First, we analyzed the temporal and spatial land loss patterns from 2001 to 2016 in the study area. Second, logistic regression, extreme gradient boosting (XGBoost), and random forest models with 15 human and natural variables were carried out during each five-year and the fifteen-year period to delineate the short- and long-term land loss mechanisms. Finally, we simulated the land-loss probability in 2031 using the optimal model. The results indicate that land loss patterns in different parts change through time at an overall decelerating speed. The oil and gas well density and subsidence rate were the most significant land loss drivers during 2001-2016. The simulation shows that a total area of $180 \mathrm{~km}^{2}$ of land has over a $50 \%$ probability of turning to water from 2016 to 2031. This research offers valuable information for decision-makers and local communities to prepare for future land cover changes, reduce potential risks, and efficiently manage the land restoration in coastal Louisiana.
\end{abstract}

Keywords: land loss; spatial-temporal analysis; coupled natural-human systems; extreme gradient boosting; random forest; coastal Louisiana

\section{Introduction}

From the beginning of the 20th century, coastal areas have drawn increasing attention from scientists and governments because of the growing population in those regions and the vital ecosystem resources they provide. However, coastal regions confront various threats from the changing environment, especially the land loss caused by coastal erosion, eustatic sea-level rise, subsidence, and human activities, e.g., oil and gas exploration [1-3]. According to the long-term global observations of coastal land erosion and accretion, the total eroded land from 1984 to 2015 is $28,000 \mathrm{~km}^{2}$, twice the surface of gained land [4].

Coastal Louisiana, one of the most vulnerable coastal regions worldwide, offers various ecosystem services and is of critical economic importance. Louisiana's wetlands comprise nearly $40 \%$ of the U.S.'s continental wetlands, which serve as habitats for many species and buffer zones for coastal communities from the frequent natural hazards [5-7]. 
Coastal Louisiana also produces more petroleum and natural gas than any other state in the nation, contains nearly $30 \%$ of the commercial fishing landings of the contiguous United States, and serves as an international harbor for maritime transportation [8-10].

Meanwhile, coastal Louisiana, like many other coastal areas, suffers from statewide land loss. From 1932 to 2000, southern Louisiana has lost an estimated $4921 \mathrm{~km}^{2}$ of land to open water [11]. A recent study reveals that the Mississippi Delta in coastal Louisiana lost wetlands at a speed of $125 \mathrm{~km}^{2}$ per year from 1983 to 2016 [12]. The disappearing wetlands lessen the available habitats for many vulnerable species and thus affect the coastal biodiversity. Meanwhile, the decreasing buffer zone increases the risk of residents and infrastructures from frequent natural hazards. Therefore, understanding and projecting the land loss process is critical for governments and residents to prepare for the changes in environmental threats, develop mitigation and protection strategies, and make better restoration and relocation decisions.

This study analyzed the land cover changes in Louisiana Coastal Zone (LCZ) and developed a regional land-loss model through statistics and machine-learning algorithms. The objectives are three-fold: (1) to reveal the short-term and long-term spatial-temporal variation of land loss patterns in LCZ during 2001-2016; (2) to identify significant land-loss variables and quantify land loss mechanisms in the study area at two temporal scales; (3) to predict land loss possibilities in 2031 under different scenarios. The results offer valuable insights into land loss mechanisms and predictions, which will help decision-makers and local communities to reduce potential risks from future land cover changes, and efficiently manage the land restoration and population relocation in coastal Louisiana. The developed modeling framework could be customized to investigate land loss patterns in other coastal regions facing similar issues. The knowledge gained from coastal Louisiana could also inform other vulnerable coastal regions globally to reduce threats and potential damages from land loss.

This article proceeds as follows. We first briefly review previous investigations into land loss patterns and mechanisms in coastal Louisiana in Section 2. Sections 3 and 4 detail the methodology of collecting, processing, and analyzing land loss data and relevant human-environmental variables. The spatial-temporal land loss patterns, mechanisms, and simulation results are summarized in Section 5. Finally, Section 6 concludes the findings of the study, discusses the methodological uncertainties, and provides suggestions for future research.

\section{Study Area}

Louisiana Coastal Zone is located in southern Louisiana, USA, and is adjacent to the northern Gulf of Mexico (ca. $88^{\circ} 45^{\prime}-93^{\circ} 54^{\prime} \mathrm{W}$ and $28^{\circ} 51^{\prime}-30^{\circ} 29^{\prime} \mathrm{N}$ ). It encompasses 20 parishes and covers an area of $42,000 \mathrm{~km}^{2}$ (Figure 1). According to the Coastal Protection and Restoration Authority (CPRA) of Louisiana 2017 Coastal Master Plan, Louisiana is in the midst of a land loss crisis that has claimed approximately $5179 \mathrm{~km}^{2}$ of land since the 1930s [13]. A recent study by Couvillion (2017) also shows that the land area in coastal Louisiana has decreased approximately $5000 \mathrm{~km}^{2}$ from 1932 to 2016 [14]. Because of the severe land loss, this area has been highly engineered with over 50 restoration and risk reduction projects since 2017 to rebuild or sustain lands [15].

However, the land loss pace has gradually slowed down, according to a series of cartographic depictions of Louisiana land cover changes, due to the implementation of coastal protection policies, wetland building, and restoration projects [16]. Roy et al. [12] analyzed nearly 4800 Landsat images and found that the land loss rate fell from nearly $90 \mathrm{~km}^{2}$ per year between 1983 and 1986 to no more than $30 \mathrm{~km}^{2}$ per year between 2010 and 2013. 


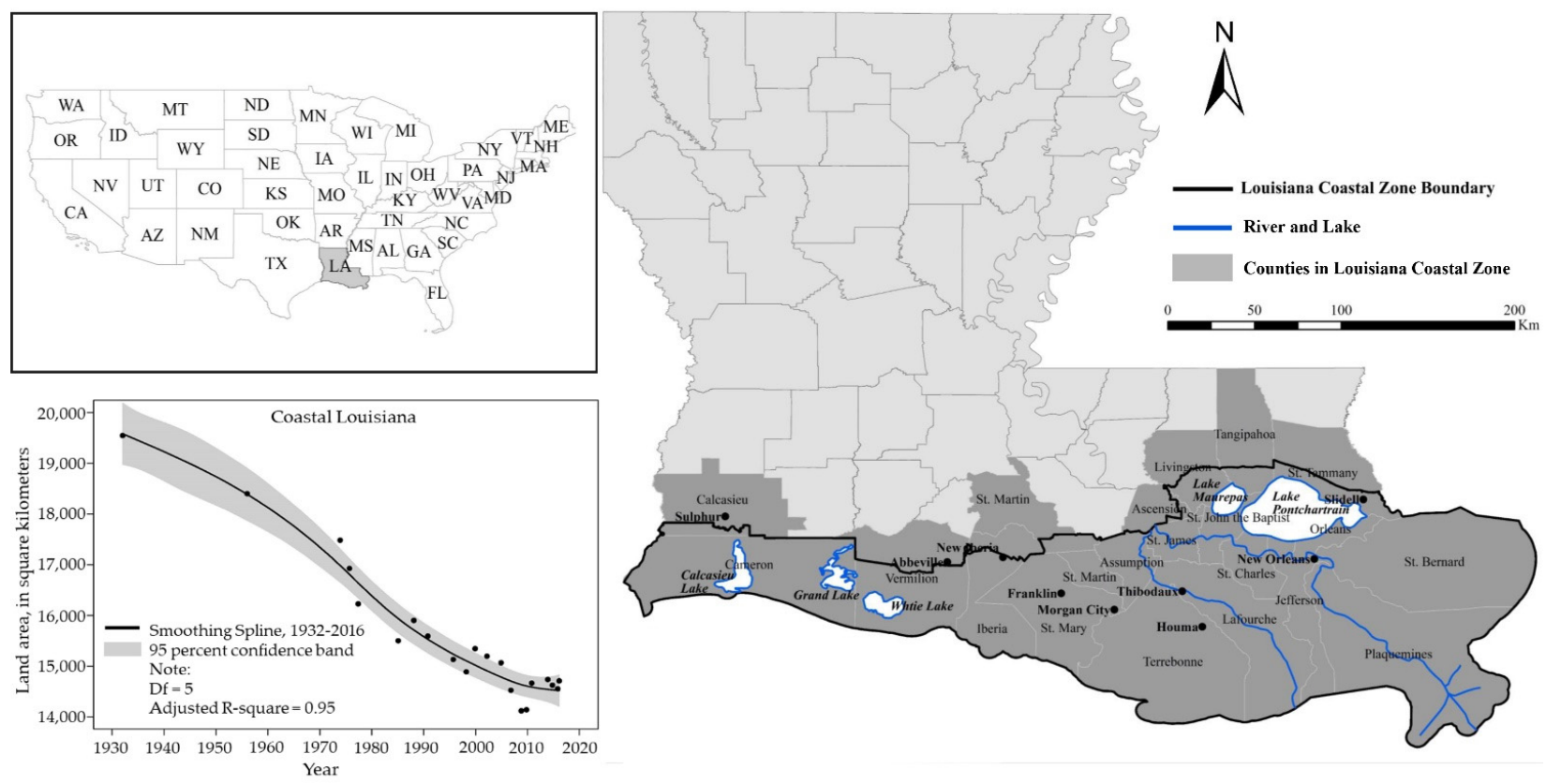

Figure 1. Louisiana coastal zone.

\section{Related Research}

Numerous studies have attempted to model and simulate land loss in coastal Louisiana using theoretical or data-driven approaches. For instance, Qiang and Lam [17] used artificial neural networks and cellular automata to model land use/cover changes in southeastern Louisiana and projected a total of $263 \mathrm{~km}^{2}$ wetland loss from 2006 to 2016. Zou et al. [18] evaluated the impact of subsidence on land loss in the Lower Mississippi River Basin and calculated a growing increase in areas vulnerable to land loss from $44.3 \mathrm{~km}^{2} /$ year in 2011 to $240.7 \mathrm{~km}^{2}$ /year in 2050. Reed et al. [1] modeled wetland losses in coastal Louisiana under three sea-level rise scenarios. They found that the scenario of a two-meter eustatic sea-level increase from 1992 to 2011 could trigger a wetland loss of over $10,000 \mathrm{~km}^{2}$ in the next 50 years. Glick and others used the Sea Level Affecting Marshes Model (SLAMM) to investigate the impact of sea-level rise rates on Louisiana coastal wetlands. Their results indicate that potential wetland losses range from $2188.97 \mathrm{~km}^{2}$ under the lowest sea-levelrise scenario to $5875.27 \mathrm{~km}^{2}$ under the highest sea-level-rise scenario by 2100 [19].

Meanwhile, abundant investigations discussed the potential human activities and environmental variables contributing to the land loss process. Olea and Coleman [20] verified that the exploitation of subsurface geologic resources significantly accelerates the land loss in coastal Louisiana. Lam et al. [21] revealed that land patches with higher fragmentation tend to have more land loss, and land protection may be most effective by prioritizing areas with the least fragmented land patches. Matthew and Gottardi [3] integrated 3D seismic data, well logs, high-resolution topographic mapping, and historical aerial photography to understand the land loss process. They found that coastal Louisiana's land loss is more severe in high-subsidence-rate areas. Abundant literature has demonstrated that sea-level rise is a significant variable of coastal Louisiana's land loss [22-25].

Nevertheless, several challenges exist in quantitatively modeling land loss dynamics and simulating future land cover patterns in vulnerable coastal regions. First, datasets of the land loss process and driving variables covering the whole coastal area are either unavailable or inconsistent in formats and resolutions $[17,18]$. There is a need to convert those diverse datasets into the same scales and formats before integrating them for modeling land loss patterns. Second, the land loss mechanism in coastal Louisiana is unclear $[18,21,26]$. Although previous work has tested the linear relationship between land loss and one or a few variables $[3,21,25]$, the compounding effects of multiple variables on land loss probability and their non-linear relationships are scarcely studied. Third, the land loss 
mechanisms in the same region might change over time [27]. There is little research modeling and comparing the changing spatial dynamics of land loss over different timescales. Understanding whether the land loss mechanism in coastal Louisiana is consistent through time necessitates further investigation.

\section{Materials}

\subsection{Land Use and Land Cover Data}

Land use and land cover (LULC) data were accessed from the National Land Cover Database (NLCD) provided by the Multi-Resolution Land Characteristics Consortium (https: / / www.mrlc.gov/data, accessed on 15 November 2021). The data were produced from Landsat 5 Thematic Mapper (TM) and Landsat 8 Enhanced Thematic Mapper Plus $(\mathrm{ETM}+)$ images through field sampling, validation, and standard quality control review procedures to ensure high classification accuracy and consistency across space and time [28]. We chose the NLCD dataset because it has been demonstrated as a reliable source to analyze and model LULC changes at regional and national scales [17,29-31].

The spatial resolution of the NLCD dataset is $30 \mathrm{~m}$ by $30 \mathrm{~m}$, translating to around 46.8 million pixels in the study area. The original LULC data include 20 land cover categories in every two or three years from 2001 to 2019 (LULC data in 1992 are also available in NLCD but not comparable to later editions). LULC data in 2001, 2006, 2011, and 2016 were chosen in this research. The study area contains 15 original LULC types (Table 1). We categorized the 15 types into six main classes (water, urban, barren, wetland, agricultural land, and vegetation) based on the Anderson land use/land cover classification system to investigate the impacts of neighboring land cover types on land loss probabilities [32]. The six LULC types were further grouped into land and water to model the spatial-temporal land loss patterns.

Table 1. The original and reclassified NLCD land cover types.

\begin{tabular}{|c|c|c|}
\hline Original Land Cover & Anderson's Land Cover Classification & Land/Water Categories \\
\hline Water & Water & Water \\
\hline Developed, Open Space & \multirow{4}{*}{ Urban } & \multirow{14}{*}{ Land } \\
\hline Developed, Low Intensity & & \\
\hline Developed, Medium Intensity & & \\
\hline Developed, High Intensity & & \\
\hline Barren Land & Barren & \\
\hline Deciduous Forest & \multirow{5}{*}{ Vegetation } & \\
\hline Evergreen Forest & & \\
\hline Mixed Forest & & \\
\hline Shrub/Scrub & & \\
\hline Herbaceuous & & \\
\hline Hay/Pasture & \multirow{2}{*}{ Agriculture } & \\
\hline Cultivated Crop & & \\
\hline Woody Wetlands & \multirow{2}{*}{ Wetlands } & \\
\hline Emergent Herbaceuous Wetlands & & \\
\hline
\end{tabular}

\subsection{Human-Environmental Variables}

We selected 15 variables to analyze land loss mechanisms in different periods based on a review of previous literature $[17,18,21,33]$. These variables could be classified into three categories: environment, neighborhood conditions, and human activity (Table 2). The environment variables include elevation, soil type, original land cover, Moran's I, distance 
to water, and subsidence rate. Previous work suggests that land loss is more likely to happen in lower elevation and higher subsidence rate areas [18,27,34]. Soil type could affect the subsidence rate and vegetation cover in coastal regions and indirectly impact the land loss probability $[35,36]$. It has been confirmed that coastal areas closer to water have significantly higher subsidence rates and are more vulnerable to the rising sea level, leading to a greater risk of land loss [37]. The Moran's I was tested as a critical land loss variable in Coastal Louisiana at the $51 \times 51$ window size [21]. Additionally, the original LULC is an important variable since land loss is more likely to happen in certain land cover types, e.g., coastal wetlands [12,17].

Variables in neighborhood conditions are the neighborhood effect of different land use types. Many LULC studies indicate that the land cover change has significantly positive spatial autocorrelation $[38,39]$. The LULC change of one land cell in the next period is closely related to the LULC types of its neighboring cells. Therefore, the numbers of neighboring water, urban, barren, vegetation, agriculture, and wetland pixels were included in the experiment.

This study considered the oil and gas well density, distance to urban areas, and distance to roads as human activity indicators. The extensive exploitation of oil and gas resources in coastal regions has been confirmed to contribute to the high wetland loss rate $[26,40]$. The distance to urban areas and roads represents the level of urbanization [41], which affects the variation of land loss rates because newly developed urban areas are prone to be adjacent to existing urban areas and land loss areas tend to be away from urban areas $[17,42]$.

Table 2. Sources and formats of input variables.

\begin{tabular}{|c|c|c|}
\hline Variables & Data Source & Original Format \\
\hline \multicolumn{3}{|c|}{ Environment } \\
\hline Elevation & $\begin{array}{l}\text { SRTM } 1 \text { Arc-Second Global from US } \\
\text { Geological Survey }\end{array}$ & $\begin{array}{c}\text { Raster } \\
(30 \mathrm{~m} \times 30 \mathrm{~m})\end{array}$ \\
\hline Soil type & $\begin{array}{l}\text { National Cooperative Soil Survey and } \\
\text { supersedes the State Soil Geographic }\end{array}$ & Polygon \\
\hline Subsidence rate & $\begin{array}{l}\text { NOAA's National Geodetic Survey, recorded } \\
\text { from } 1920\end{array}$ & Point \\
\hline Original land cover & $\begin{array}{l}\text { NOAA Coastal Service Center, updated in } \\
\text { 2001, 2006, } 2011 \text { and } 2016\end{array}$ & $\begin{array}{c}\text { Raster } \\
(30 \mathrm{~m} \times 30 \mathrm{~m})\end{array}$ \\
\hline Moran's I & Same as above & Same as above \\
\hline Distance to water & Same as above & Same as above \\
\hline \multicolumn{3}{|c|}{ Neighborhood Conditions } \\
\hline Number of water cells & \multirow{6}{*}{$\begin{array}{l}\text { NOAA Coastal Service Center, updated in } \\
22001,2006,2011 \text { and } 2016\end{array}$} & \multirow{6}{*}{$\begin{array}{c}\text { Raster } \\
(30 \mathrm{~m} \times 30 \mathrm{~m}) \\
\text { Neighborhood size: } \\
3 \times 3 \text { cells }\end{array}$} \\
\hline Number of urban cells & & \\
\hline Number of barren cells & & \\
\hline Number of vegetation cells & & \\
\hline Number of agriculture cells & & \\
\hline Number of wetland cells & & \\
\hline \multicolumn{3}{|c|}{ Human Activity } \\
\hline Oil/gas well density & Louisiana Department of Natural Resource & Point \\
\hline Distance to road & $\begin{array}{l}\text { US Census Bureau, updated in 2000, 2006, } 2011 \\
\text { and } 2016\end{array}$ & Polyline \\
\hline Distance to urban & $\begin{array}{l}\text { NOAA Coastal Service Center, updated in } \\
\text { 2001, 2006, } 2011 \text { and } 2016\end{array}$ & $\begin{array}{c}\text { Raster } \\
(30 \mathrm{~m} \times 30 \mathrm{~m})\end{array}$ \\
\hline
\end{tabular}

The original input datasets were collected from different resources in diverse formats, which were then converted to raster layers in the same two-dimensional array of 30-by$30 \mathrm{~m}$ cells for the subsequent analysis. Simple Kriging interpolation and point density 
methods were used to acquire the state-wide subsidence rates and oil/gas well densities. Euclidean distance was used to calculate the proximity variables. Focal statistics were used to sum cells by LULC types in a 3 by 3 window to explore the neighborhood effect. The landscape fragmentation levels were represented as the Moran's I of the land/water map at $51 \times 51$ grid size, as suggested in Lam et al. [21]. Finally, all the selected input variables were linearly normalized to the range of 0 to 1 . Figure 2 shows the preprocessed data layers.

\section{Methodology}

\subsection{Statistical Analysis}

Figure 3 shows the overall workflow of this study. The first step was to calculate land loss and land gain in LCZ at different time periods to reveal their spatial and temporal patterns. In each year, land areas were assigned " 1 " and water areas were assigned " 0 ". Land changes at four periods, 2001-2006, 2006-2011, 2011-2016, and 2001-2016 were computed to show the short-term and long-term trends of land-water transitions during the 15-year period by raster calculation.

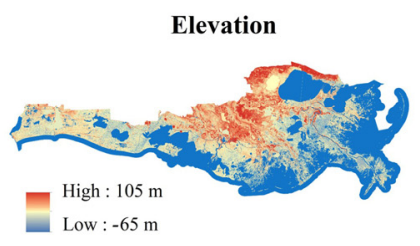

Distances to urban area

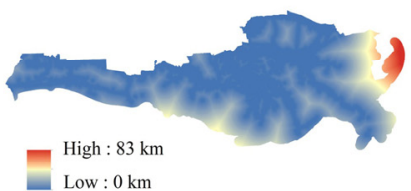

Number of urban cells

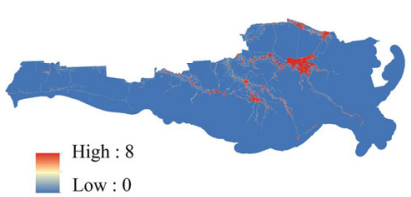

Number of agriculture cells

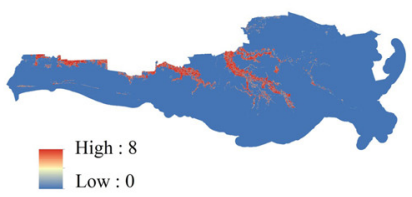

Soil type

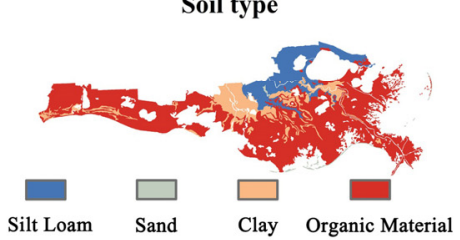

Subsidence rate

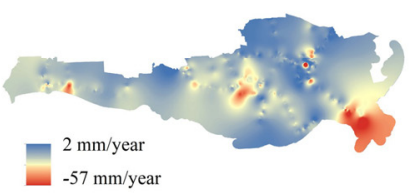

Distances to water

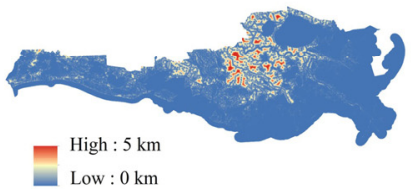

Number of water cells

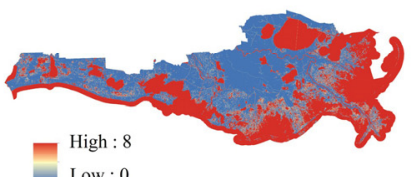

Number of barren cells

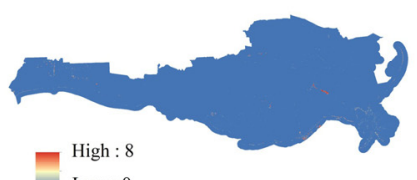

Distance to road

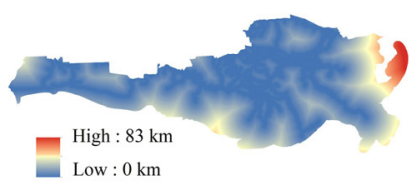

Oil/gas well density

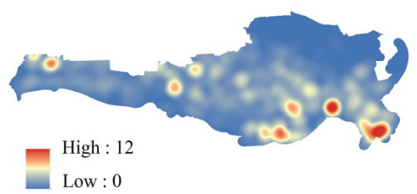

Landscape fragmentation in buffer zone

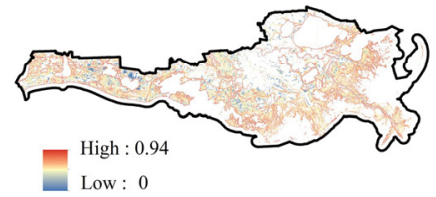

Number of vegetation cells

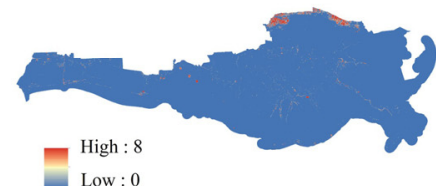

Number of wetland cells

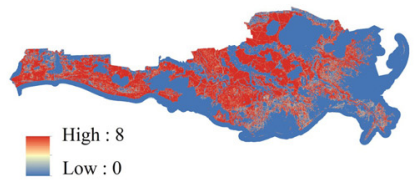

Original land use and land cover

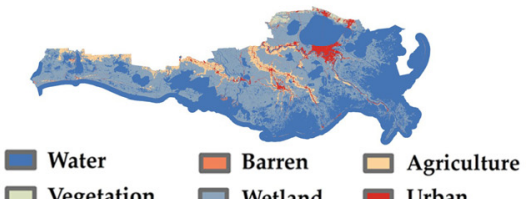

$\bigwedge^{N} \quad \begin{array}{llll}0 & 125 & 250 & 500 \mathrm{~km}\end{array}$

Figure 2. Spatial patterns of the preprocessed variables in LCZ in 2001. 
Then land loss and non-loss pixels were sampled for model building. During the model building process, the value of the land loss pixels was labeled as " 1 " and the non-loss pixels, which include unchanged and land gain pixels, were assigned " 0 ". Most land pixels tend to stay in their previous states, which means land loss pixels consist of a small portion of the whole study area. The imbalanced land loss vs. non-loss pixel ratio is unsuitable for conducting regression analysis and can affect the classification accuracy when building machine learning models, e.g., random forest models [43]. Therefore, we adopted the following processing to balance the land loss vs. non-loss pixel ratio. Initially, we created the histograms of the conditional probability of land loss by each variable to reveal the non-linear relationships between variables and land loss probabilities. Buffer analysis was then applied based on the histograms to narrow down the study area to high land loss probability zones. Finally, we selected all land loss pixels and randomly selected 2.5 times of the land loss " 1 " pixels from non-loss " 0 " pixels in the buffered area for each period.
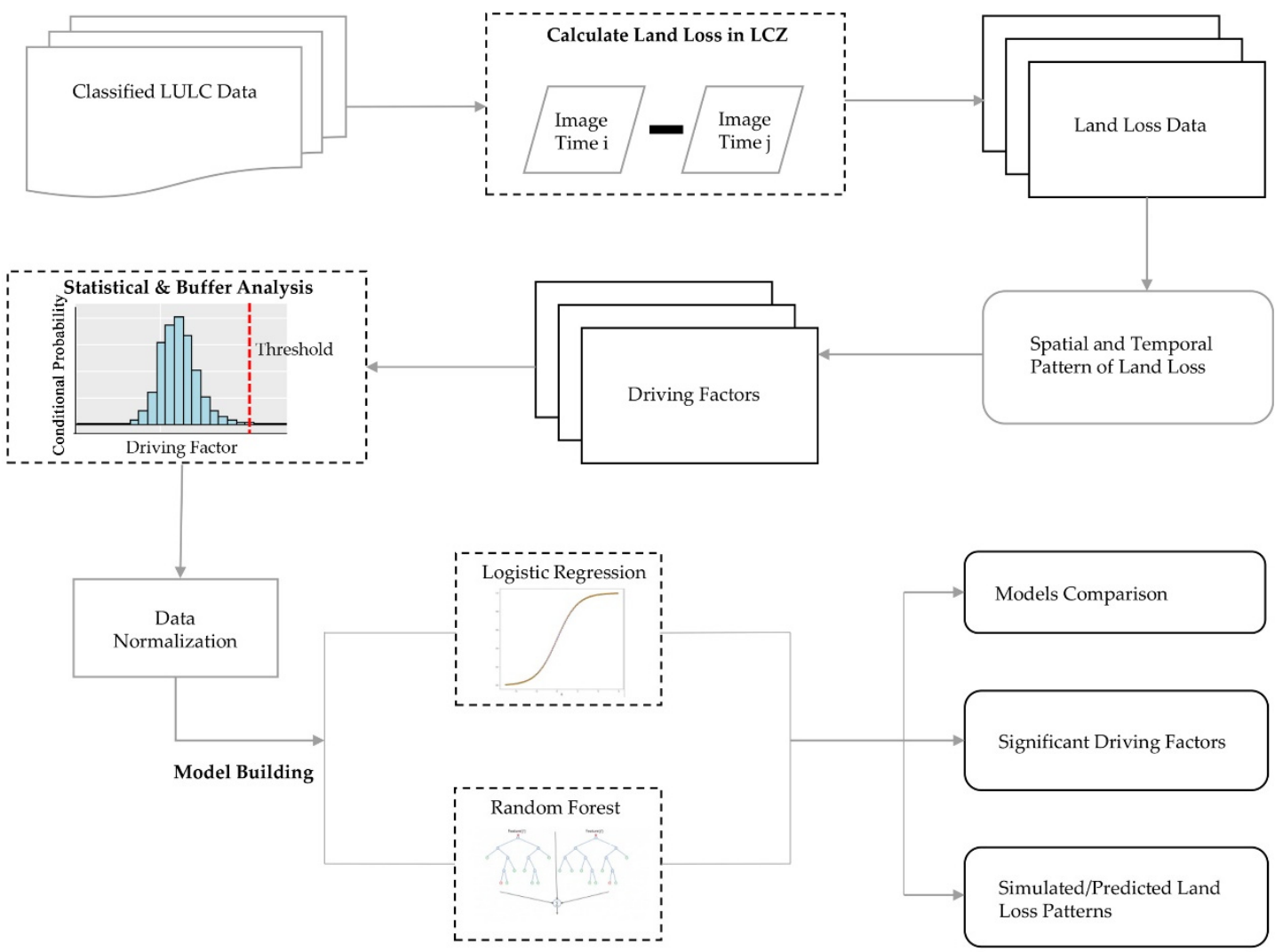

Figure 3. The workflow of this study.

We calculated Pearson's correlation coefficients between each pair of the fifteen variables to assess and eliminate multicollinearity. If the correlation coefficient between any two variables was greater than 0.6 [44], we selected the variable that has a higher correlation with land loss probabilities for the subsequent land loss modeling and forecasting. This method yields twelve variables, including elevation, subsidence rate, distances to urban and water, numbers of neighboring water, urban, barren, vegetation, and agriculture cells, Moran's I, the original land cover type, and oil/gas well density.

\subsection{Machine Learning}

This research employed three popular supervised classification models, (1) multivariable stepwise Logistic Regression (LR) model as a baseline model, (2) eXtreme Gradient Boosting (XGBoost) model, and (3) Random Forest (RF) model to investigate the compounding effects of environmental conditions and human activities on the land loss in four time periods. 
LR is a linear regression algorithm with a discrete dependent variable. Compared with other machine learning algorithms, it could be viewed as a white box model which is able to establish the linear relationship between variables and the land loss probability. The land loss probability $P(x)$ is related with variables $x$ by the logit function, as shown in Equation (1):

$$
P(x)=\frac{1}{1+e^{-\left(a+\beta_{1} x_{1}+\beta_{2} x_{2}+\cdots+\beta_{k} x_{k}\right)}}
$$

where $\alpha$ is the constant, $\beta_{k}$ is the coefficient of independent variable $x_{k}$, which is the land loss driving variable in this study. The LR method could reveal the effect of each variable on land loss through the variable's estimated coefficient.

$\mathrm{RF}$ is a non-linear ensemble classification algorithm that uses decision trees as base classifiers. Each decision tree is trained using a subset of data randomly sampled from the whole input dataset and taking a random selection of features rather than using all features, referred to as the bagging method [45]. The RF algorithm splits the input variables into independent groupings based on the bagging algorithm and applies the Gini Index to generate optimized tree structures for classification [46]. The relative importance of each variable in the RF model could be derived by measuring the classification error ratio increase in out-of-bag data when the variable value was permuted randomly [47].

$X$ GBoost is an efficient and scalable implementation of a gradient-boosting framework and has been a popular method in recent years [48]. The principle of XGBoost is to produce a prediction model in the form of a boosting ensemble of weak classification trees by a gradient descent that optimizes the loss function [48]. XGBoost has better control against overfitting by using more regularized model formalizations. It is highly effective in reducing the computation time and can be applied in classification and regression tasks. Similar to the RF algorithm, the XGBoost model measures feature importance by calculating the performance improvement gained from each attribute split point.

To compare the three machine learning models, we need to ensure the consistency of input variables in model training. Hence, significant variables selected by the stepwise logistic regression were included in RF and XGBoost analysis. In addition, to conduct RF and XGBoost analysis, it is necessary to adjust the models' hyperparameters. A grid search for model performance optimization was carried out with the 10-fold cross-validation method based on an accuracy metric.

\subsection{Accuracy Analysis}

The numbers of pixels for training models were determined by the land loss area and different in each period: 915,864 in 2001-2006, 611,696 in 2006-2011, 401,262 in 2011-2016, and 901,117 in 2001-2016. In each period, $70 \%$ of the pixels was selected for model training, and the remaining 30\% was used for cross validation. The Area Under Curve (AUC) value, classification accuracy, precision, recall, and F1 score were used to evaluate the effectiveness of LR, RF and XGBoost models (Equations (2)-(6)). AUC measures the area under the receiver operating characteristic (ROC) curve. An area of 1 represents a perfect test, and 0.5 means a random test [49]. Accuracy is the ratio of correct classifications to all instances. Precision is the fraction of correctly identified land loss pixels (True Positive, TP) among all modeled land loss pixels (TP and False Positive, FP), while recall is the fraction of TP pixels among all actual land loss pixels (TP and False Negative, FN). F1 score is the harmonic mean of recall and precision. Precision, recall, and F1 score are demonstrated as preferred measures to evaluate the performance of models developed from uneven datasets [50].

$$
\mathrm{AUC}=\frac{\sum_{t_{0} \in D^{0}} \sum_{t_{1} \in D^{1}} 1\left[f\left(t_{0}\right)<f\left(t_{1}\right)\right]}{\left|D^{0}\right| *\left|D^{1}\right|}
$$


where $1\left[f\left(t_{0}\right)<f\left(t_{1}\right)\right]$ denotes an indicator function which returns 1 if $f\left(t_{0}\right)<f\left(t_{1}\right)$ and 0 otherwise; $D^{0}$ is the set of negative examples, and $D^{1}$ is the set of positive examples.

$$
\begin{gathered}
\text { Accuracy }=\frac{\mathrm{TP}+\mathrm{TN}}{\mathrm{TP}+\mathrm{TN}+\mathrm{FP}+\mathrm{FN}} \\
\text { Precision }=\frac{\mathrm{TP}}{\mathrm{TP}+\mathrm{FP}} \\
\text { Recall }=\frac{\mathrm{TP}}{\mathrm{TP}+\mathrm{FN}} \\
\text { F1-score }=2 * \frac{\text { Precision } * \text { Recall }}{\text { Precision }+ \text { Recall }}
\end{gathered}
$$

\section{Results}

\subsection{Spatial and Temporal Patterns of Land Change}

Figure 4 a shows the temporal changes in total land and water areas in the study area in the four years. The land area was 100 and $200 \mathrm{~km}^{2}$ more than the water area in LCZ in 2001 and 2016. An opposite pattern was observed in 2006 and 2011: that the land area was nearly $100 \mathrm{~km}^{2}$ less than the water area. The land loss crisis was more severe during 2001-2006, with a net land loss area of over $100 \mathrm{~km}^{2}$. On the contrary, net land gains were detected during the other two 5-year periods (Figure 4b). Over fifteen years, LCZ's land loss area was more than $200 \mathrm{~km}^{2}$, while the land gain area was nearly $300 \mathrm{~km}^{2}$. The land/water fluctuation was further investigated by quantitatively analyzing the land/water transitions of the same pixel over different periods. Among 923,596 pixels that experienced at least one land/water transition from 2001 to 2016, 28.02 and 33.09\% of them went through land loss and land gain and remained as water and land, respectively. Another $24.68 \%$ went through a land-water-land transition, while $9.49 \%$ underwent a water-land-water conversion. The remaining $4.72 \%$ of pixels shifted their statuses from land to water or water to land every five years.

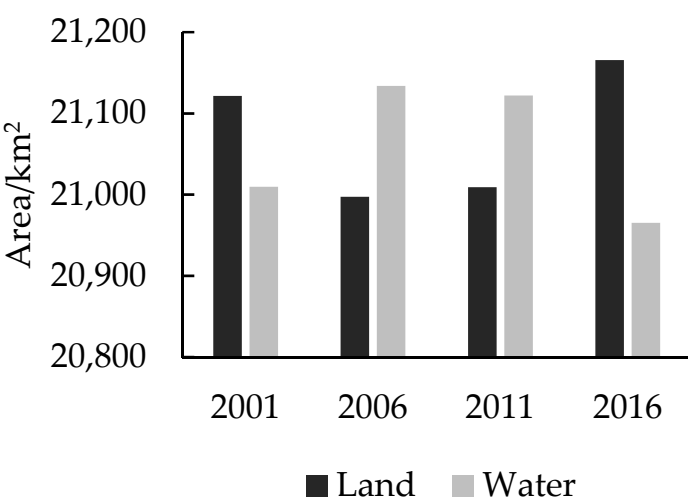

(a)

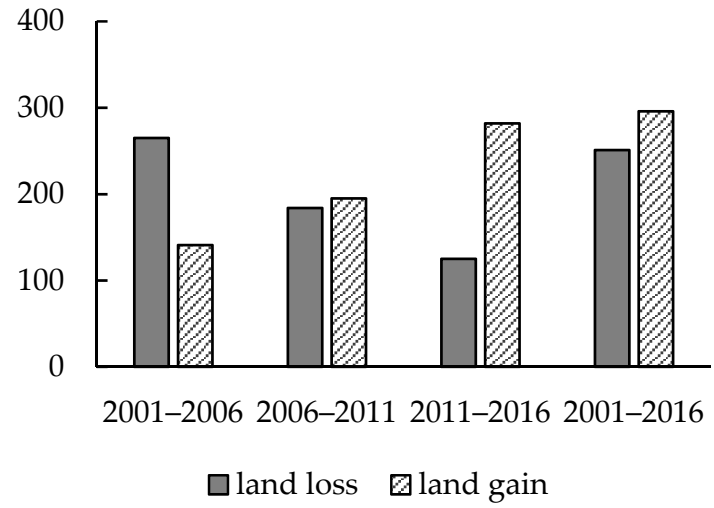

(b)

Figure 4. Land - water transitions in LCZ from 2001 to 2016. (a) Land and water area. (b) Land loss and land gain.

Since the changed land/water area occupied a small part of the study area in each period, geographically visualizing land loss and land gain is challenging. Therefore, the Aggregated Change Index (ACI) representing the ratio of land loss pixels within the neighborhood of a 50-pixel radius circle was applied to each pixel to make the changed pixels more visible [17]. ACI values range from -1 to 1 , where a negative value represents a $100 \%$ land gain, and a positive value indicates a $100 \%$ land loss in the buffered circle of each pixel. 
The ACI values in different periods reveal the spatial-temporal land loss and land gain patterns (Figure 5). In 2001-2006, land loss in LCZ was much more severe in the central and eastern coastal regions. The land loss crisis slowed down from 2006 to 2011, and land loss areas were mainly in the western and central LCZ. From 2011 to 2016, LCZ went through a statewide coastal land gain with local land loss observed along the western coastline. In the long-term period (2001-2016), land loss areas mainly concentrated in the Mississippi Delta, the middle of the Terrebonne Basin, and western regions, while land gain was detected in southeast coastal regions. The statewide patterns are consistent with the study conducted by Roy et al. [12] comparing land loss speeds between 1983-1999 and 1999-2016 in Atchafalaya-Vermillion and Barataria, which found decelerating land loss in the two basins.

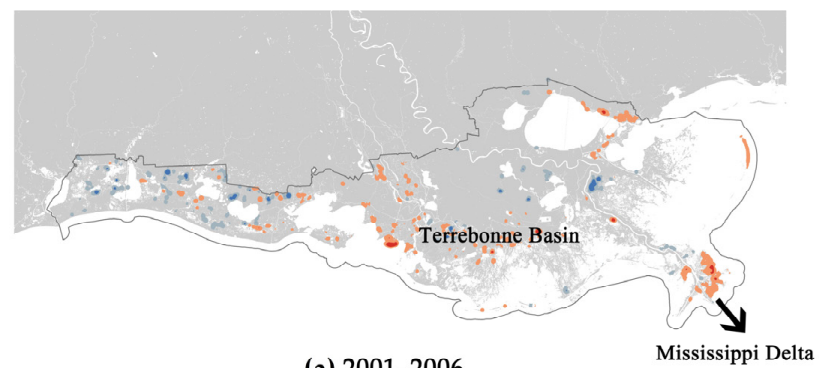

(a) 2001-2006

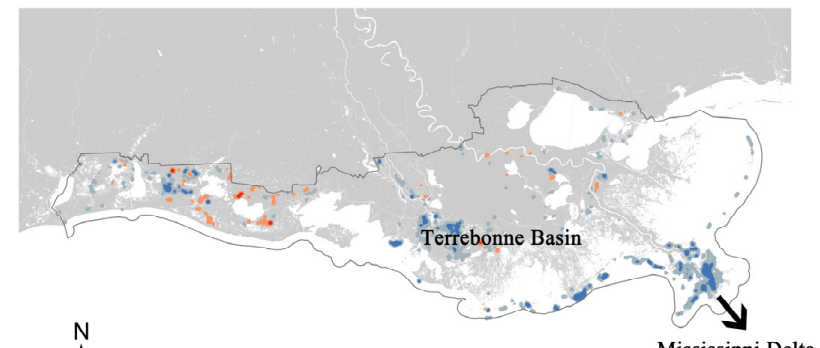

$\begin{array}{ll}N & \text { (c) 2011-2016 }\end{array}$

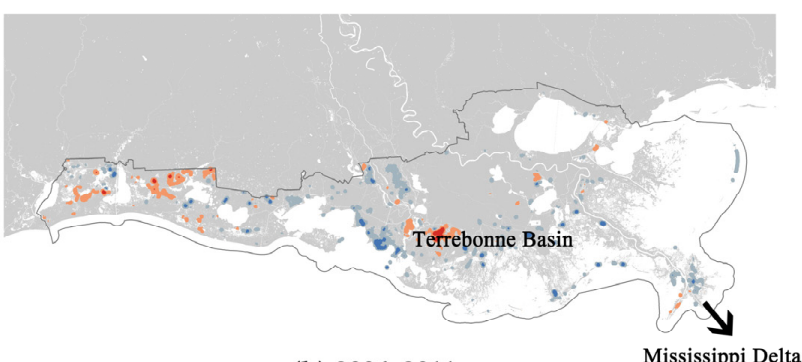

(b) 2006-2011

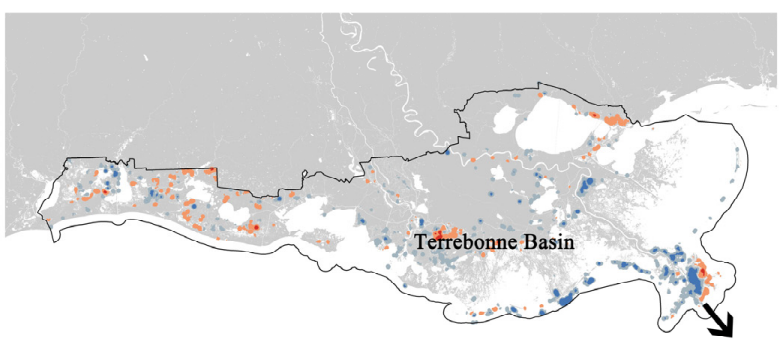

(d) 2001-2016
Mississippi Delta

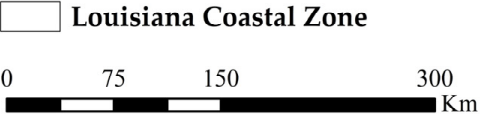

ACI
$-0.65--0.10$

$-0.10--0.02$

$0.04-0.20$

$0.20-0.60$

Figure 5. Spatial-temporal patterns of aggregated land change index (ACI) in LCZ.

\subsection{The Relationship between Land Loss and Selected Variables}

Figure 6 displays the conditional probability distributions of land loss by the 15 variables during every five years and the whole period, unraveling different variables' distinct impacts on the land loss probability. Because land loss pixels consist of a small portion of the whole study area, the conditional probability was multiplied by 1000 . The relationships between the land loss probability and elevation, distance to water, subsidence, and oil/gas well density is generally monotonic in all three short-term and whole periods. The land loss probability is higher in areas with lower elevation. The land loss process primarily took place in areas within $250 \mathrm{~m}$ from the water, and the probability decreases exponentially with the increase in the distance to water areas. Areas with faster subsidence speed and greater oil/gas well density also present higher land loss probability. 

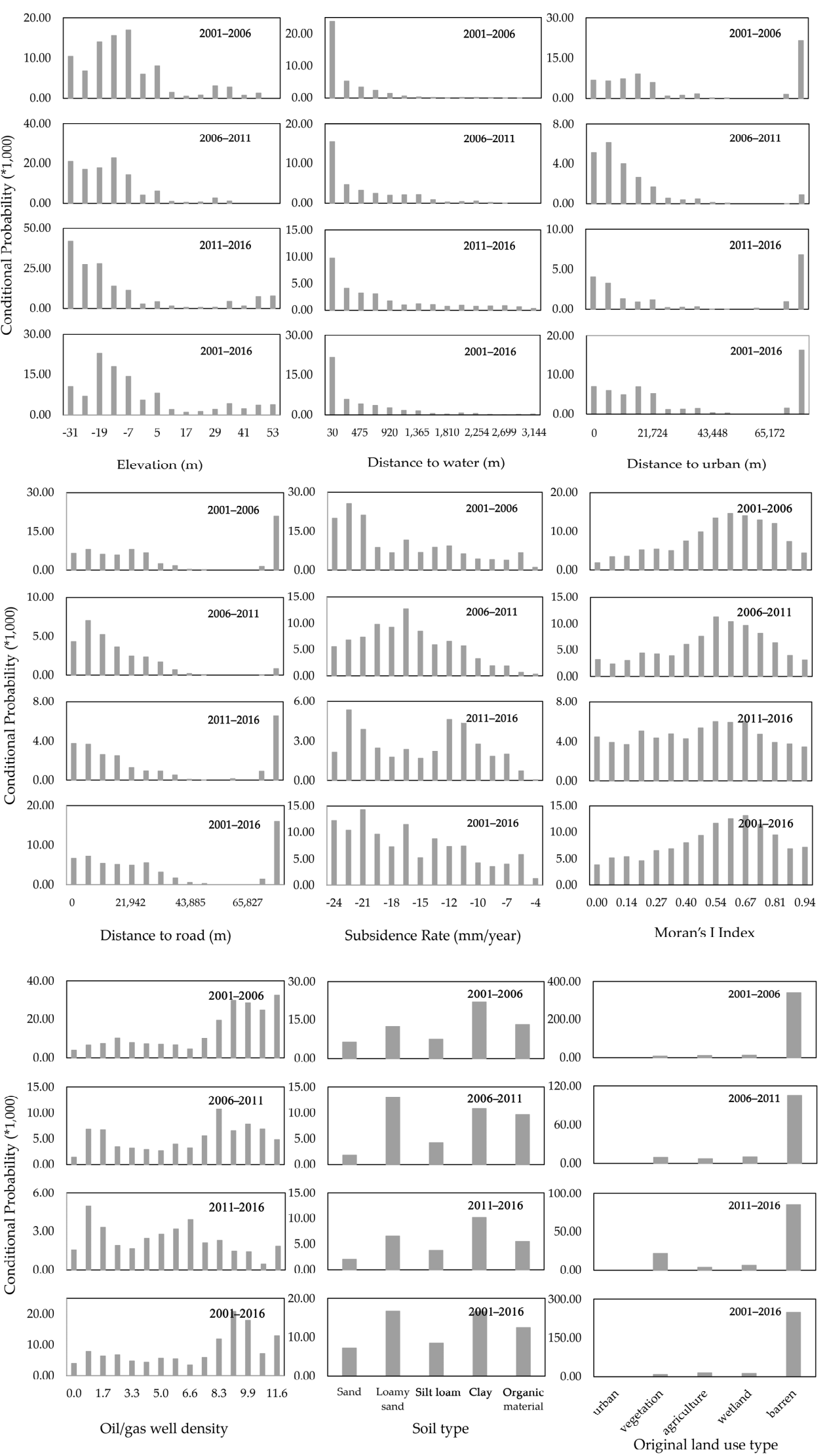

Figure 6. Cont. 

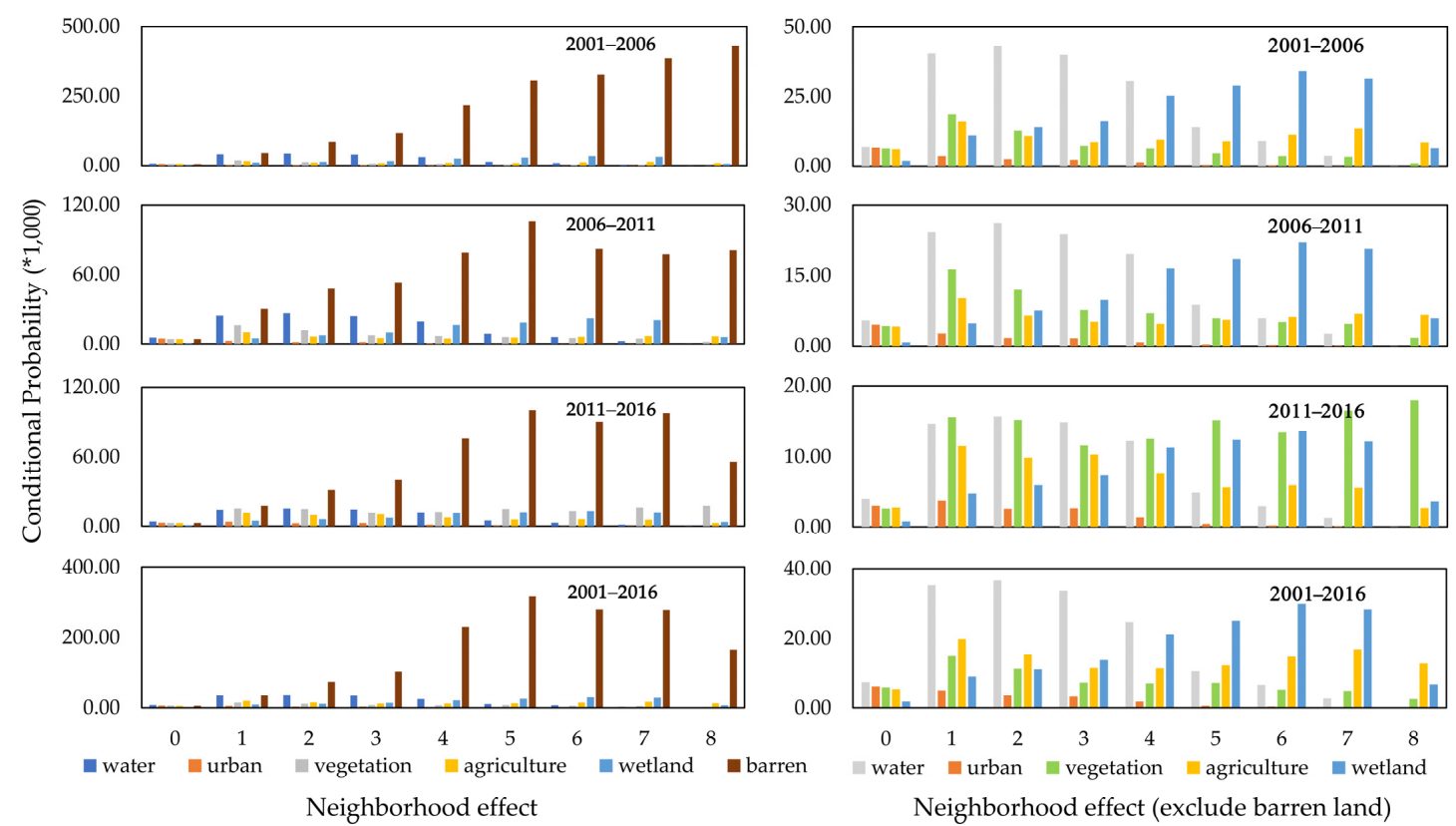

Figure 6. Conditional land loss probability by different variables.

Nonlinear relationships between land loss probability and a few variables were observed. Although areas distant from urban and roads had the highest land loss probability from 2001 to 2016, regions closer to urban or roads also showed high land loss probability. Fragmentation plays a positive role in the land loss process, but conditional probability reveals that land pixels with the Moran's I index between $0.5-0.7$ are more likely to become water in LCZ.

Categorical land characteristics also affect the land loss probability. Land loss is more likely to happen if the soil type is clay or organic material. Barren land had a significantly higher land loss rate than other land cover types during the fifteen years. Land loss pixels had more barren/wetlands pixels and fewer urban/water pixels in their surroundings. The neighborhood effect of vegetation does not consistently impact the land loss probability.

The conditional probability analysis indicates that the majority of land loss happened in regions where the elevation was lower than $10 \mathrm{~m}$ and the distance to water was closer than $250 \mathrm{~m}$ in the fifteen years. Therefore, we defined those areas (elevation $\leq 10 \mathrm{~m}$ and distance to water $\leq 250 \mathrm{~m}$ ) as High Land-loss Probability (HLP) zones and conducted the land loss modeling and simulation within the HLP zones.

\subsection{Model Comparision}

After conducting the stepwise logistic regression analysis, the same set of 11 out of the 12 variables was found significant in each short and long-term land loss model. Those variables include elevation, oil/gas well density, Moran's I, subsidence rate, numbers of neighboring urban, barren, vegetation, agriculture and water cells, and distances to water and urban areas. Those 11 variables were utilized in both RF and XGBoost analysis to ensure the consistency of driving factors in three machine learning models. Table 3 shows the RF and XGBoost hyperparameter ranges and the optimized values detected by the grid search while considering computational costs. The optimal RF models were derived by tuning four model parameters, including the number of trees (n_estimators), the number of features at each node (max_feature), the minimum number of samples required to split a node (min_samples_split), and a statistical method for estimating a quantity from a data sample (bootstrap). Results show that RF models with 800 trees, auto max_feature, 2 min_samples_split and false bootstrap achieved the best performance in land loss classification. Four parameters in the XGBoost algorithm were adjusted, including the maximum number of iterations (nrounds), learning rate (eta), regularization control (gamma), and 
the minimum number of instances required in a child node (min_child_weight), and the optimized values are $400,0.3,0$, and 1 .

Table 3. The RF and XGBoost grid search hyperparameters.

\begin{tabular}{cccc}
\hline Model & Parameter & Range & Optimum Value \\
\hline \multirow{2}{*}{ RF } & n_estimators & 400 to 1200 & 800 \\
& max_feature & [Auto, SQRT, Log2] & Auto \\
& min_samples_split & {$[2,4,8]$} & 2 \\
& Bootstrap & [True, False] & FALSE \\
\hline XGBoost & Nrounds & 100 to 500 & 400 \\
& Eta & 0 to 1 & 0.3 \\
& Gamma & 0 to 1 & 0 \\
\hline
\end{tabular}

The performance of the optimal LR, XGBoost, and RF models is summarized in Table 4. The AUC values of the four RF models range from 0.92-0.95, which are much higher than the AUC values of the four LR models (0.70-0.75) and the four XGBoost models (0.85-0.87). The accuracy, precision, recall, and F1-score of the LR models are 0.70-0.75, 0.62-0.69, $0.20-0.32$, and $0.30-0.44$, respectively, while XGBoost and RF models yield similar values of accuracy $(0.88-0.91)$, precision $(0.83-0.88)$, recall $(0.72-0.79)$ and F1-score $(0.77-0.82)$.

Table 4. Accuracy estimation for LR, XGBoost, and RF models.

\begin{tabular}{ccccccccccccc}
\hline & \multicolumn{3}{c}{ 2001-2006 } & \multicolumn{3}{c}{ 2006-2011 } & \multicolumn{3}{c}{ 2011-2016 } & \multicolumn{3}{c}{ 2001-2016 } \\
\hline & LR & XGBoost & RF & LR & XGBoost & RF & LR & XGBoost & RF & LR & XGBoost & RF \\
\hline AUC & 0.73 & 0.86 & 0.93 & 0.70 & 0.87 & 0.95 & 0.72 & 0.85 & 0.92 & 0.75 & 0.87 & 0.95 \\
Accuracy & 0.76 & 0.89 & 0.89 & 0.75 & 0.90 & 0.90 & 0.75 & 0.89 & 0.88 & 0.76 & 0.91 & 0.91 \\
Precision & 0.69 & 0.84 & 0.85 & 0.62 & 0.86 & 0.86 & 0.64 & 0.84 & 0.83 & 0.63 & 0.88 & 0.88 \\
Recall & 0.32 & 0.77 & 0.75 & 0.31 & 0.79 & 0.78 & 0.25 & 0.76 & 0.72 & 0.20 & 0.75 & 0.74 \\
F1-score & 0.44 & 0.80 & 0.80 & 0.41 & 0.82 & 0.82 & 0.36 & 0.80 & 0.77 & 0.30 & 0.80 & 0.80 \\
\hline
\end{tabular}

The low recall values indicate that the trained LR models tend to classify more pixels as non-loss pixels and cannot fully identify land loss pixels. Considering all five evaluation matrices, the LR model trained in 2001-2006 performed the best, while the long-term LR model in 2001-2016 had the worst performance. The limited performance of the linear LR models is expected as the conditional land loss probability analysis in the previous section has demonstrated the non-linear relationships between land loss and a few driving factors.

The performance of the XGBoost and the RF models was relatively consistent in all four periods. The long-term land loss model had the highest AUC, accuracy, and precision among all four models. Comparing the five accuracy estimations shows that land loss models trained by RF algorithms outperformed models derived from LR and XGBoost in successfully recognizing most land loss pixels and avoiding identifying non-loss pixels as land loss ones. The long-term land loss model derived from the RF algorithm had the highest AUC, accuracy, and precision among all four models.

\subsection{Models Explanation}

The coefficients of the LR model for each time period are listed in Table 5, suggesting consistent linear effects of variables on land loss in four time periods. Elevation, the distance to water, and the neighborhood effect of urban areas negatively affected both short-term and long-term land loss processes in LCZ. Simultaneously, the subsidence rate and the neighborhood effects of barren, water, vegetation, and agriculture areas positively impacted the land loss probability. 
Table 5. Coefficients of the multi-variate LR model.

\begin{tabular}{|c|c|c|c|c|}
\hline & 2001-2006 & $2006-2011$ & 2011-2016 & 2001-2016 \\
\hline Elevation & -4.63 & -5.07 & -6.19 & -4.30 \\
\hline Number of urban cells & -4.10 & -4.73 & -2.68 & -3.71 \\
\hline Distance to water area & -2.55 & -1.98 & -1.56 & -2.42 \\
\hline Oil/gas well density & +0.27 & -1.68 & -1.76 & -1.14 \\
\hline Distance to urban area & +0.28 & -2.56 & -3.17 & -0.28 \\
\hline Moran's I & +0.19 & +0.26 & -0.27 & +0.61 \\
\hline Number of vegetation cells & +0.79 & +1.29 & +2.65 & +1.05 \\
\hline Number of water cells & +1.27 & +1.57 & +1.78 & +1.06 \\
\hline Number of agriculture cells & +1.15 & +0.88 & +0.73 & +1.55 \\
\hline Subsidence rate & +1.76 & +4.37 & +1.28 & +2.16 \\
\hline Number of barren cells & +4.34 & +3.11 & +4.87 & +4.15 \\
\hline
\end{tabular}

Note: all variables in each period are significant at the $p$-value of 0.001 .

The oil/gas well density, Moran's I, and the distance to urban areas have contradicting effects on the land loss probability in different periods, possibly due to collinearity between variables. Hence, we conducted the single variable LR for these three variables and summarized the results in Table 6 to figure out the impact of the three variables on the land loss probability. The effects of oil/gas well density and Moran's I on land loss were constantly positive in each short-term period, indicating that land loss is more likely to happen in more fragmented areas with higher oil and gas explorations. However, the relationship between land loss probability and the distance to urban areas changed over time. Land loss probability was higher in areas away from urban areas in 2001-2006. However, during 2006-2011 and 2011-2016, land loss probability was higher in areas closer to urban areas.

Table 6. Coefficients of the single variable LR model.

\begin{tabular}{ccccc}
\hline & 2001-2006 & 2006-2011 & 2011-2016 & 2001-2016 \\
\hline Oil/well gas density & +1.66 & +0.98 & +0.13 & +0.46 \\
Moran's I & +1.25 & +0.50 & +0.15 & +1.14 \\
Distances to urban & +2.21 & -0.08 & -0.55 & +1.49 \\
\hline
\end{tabular}

Note: all variables in each period are significant at the $p$-value of 0.001 .

Figure 7 shows the relative importance of the same set of factors computed from XGBoost and RF models. Oil and gas well density and subsidence rate were the two most important variables in all XGBoost and RF models. The Moran's I, distances to urban and water, and elevation were also significant variables with high importance scores. The effects of neighboring barren, water, urban, agriculture, and vegetation coverages were minimal on both short-term and long-term land loss processes based on XGBoost and RF models.

\subsection{Land Loss Simulation and Prediction}

We adopted the optimal RF-trained land loss model from 2001 to 2016 to simulate the land loss patterns from 2001 to 2016 and from 2016 to 2031 in the buffered HLP zone since RF models outperformed LR and XGBoost models. Because the number of the error pixels is too small to be visible in the study area, an aggregated error index (AEI) using the same concept as the ACI was introduced and applied. AEI ranges from 0 to 1 , where 0 means no simulation error and 1 indicates that all neighboring pixels are falsely predicted. Figure 8 shows the spatial pattern of the AEI based on the actual and simulated land loss in 2016. The maximum AEI value was 0.3, revealing that the RF simulated land loss is highly consistent with the actual land loss. Areas with relatively higher classification errors were in the western coastline, Mississippi River Delta, Terrebonne Basin, and along the eastern shore of Lake Pontchartrain. 


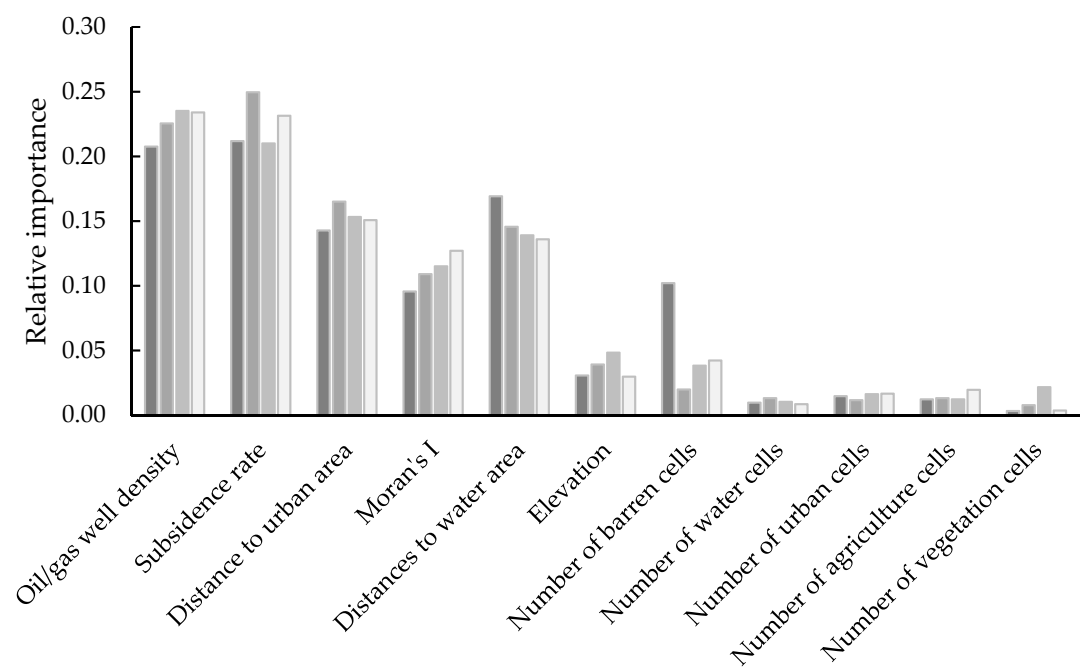

(a)

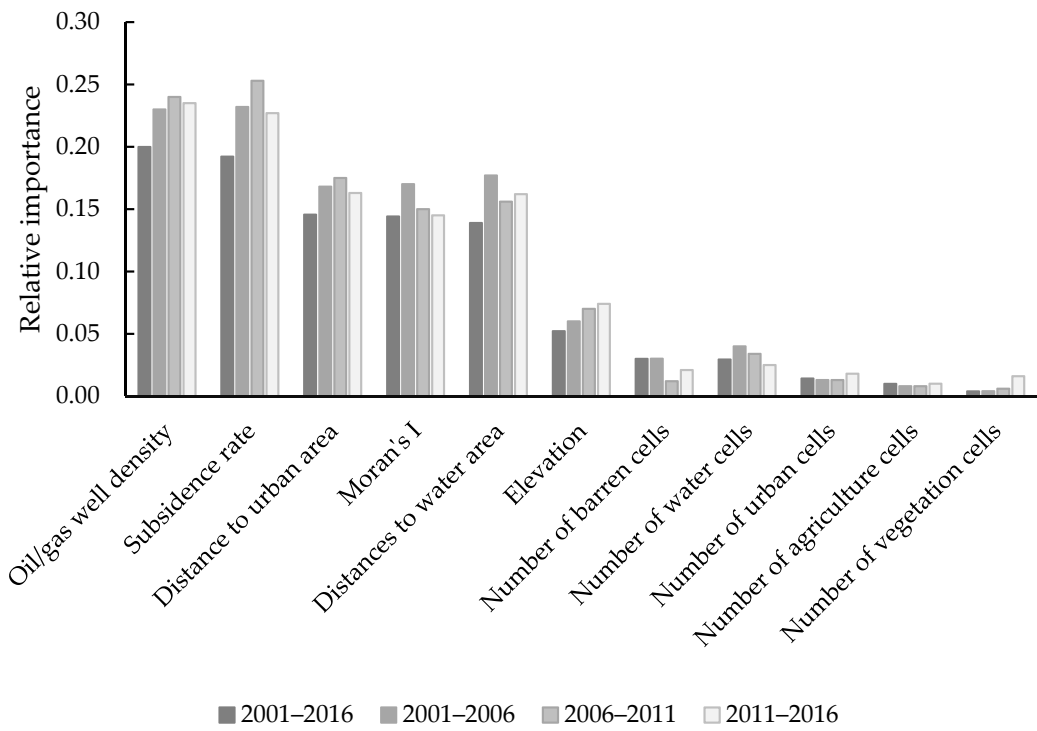

(b)

Figure 7. Relative importance of driving factors on land loss in four time periods. (a) XGBoost models. (b) RF models.

Table 7 lists the predicted land loss pixel numbers and areas in 2031 by probabilities at ten-percent intervals. The spatial patterns of simulated land loss in 2016-2031 are displayed in Figure 9. We defined and considered two scenarios in this study, moderate and severe. The moderate scenario predicts that land pixels with a land loss probability greater than $50 \%$ will convert to water in 2031 . The severe scenario classifies land pixels with a land loss probability of over $25 \%$ as land loss pixels. Under the moderate scenario, a total area of $173.19 \mathrm{~km}^{2}$ in the buffered zones is projected to be lost from 2016 to 2031 . The predicted land loss was located in the central and southeastern LCZ, especially in zones (a), (b), and (c) in Figure 9. Under the severe scenario, coastal areas in Terrebonne Basin, Barataria Basin, and Mississippi Delta would experience severe land loss, and the total forecasted land loss area was $2656.74 \mathrm{~km}^{2}$. 


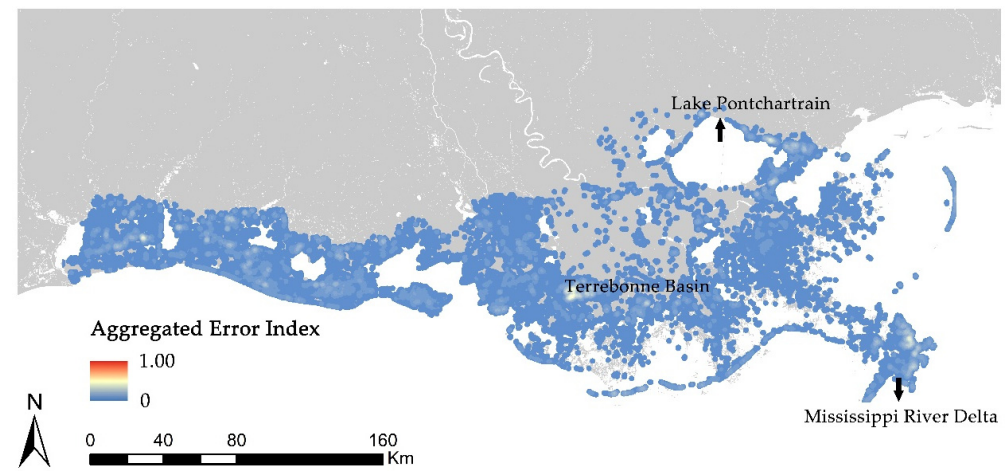

Figure 8. Aggregated error distribution of simulated land loss in 2001-2016.

Table 7. Statistics of land loss pixels and areas in the HLP zone.

\begin{tabular}{ccc}
\hline Probability of Land Loss & The Number of Pixels & Area $\mathbf{( k m}^{\mathbf{2}} \mathbf{~}$ \\
\hline $0-10 \%$ & $4,662,297$ & 4196.07 \\
$10-20 \%$ & $3,036,637$ & 2732.97 \\
$20-30 \%$ & $2,195,063$ & 1975.56 \\
$30-40 \%$ & $1,318,586$ & 1186.73 \\
$40-50 \%$ & 436,932 & 393.24 \\
$50-60 \%$ & 127,998 & 115.20 \\
$60-70 \%$ & 52,131 & 46.92 \\
$70-80 \%$ & 11,735 & 10.56 \\
$80-90 \%$ & 556 & 0.50 \\
$90-100 \%$ & 8 & 0.01 \\
\hline
\end{tabular}

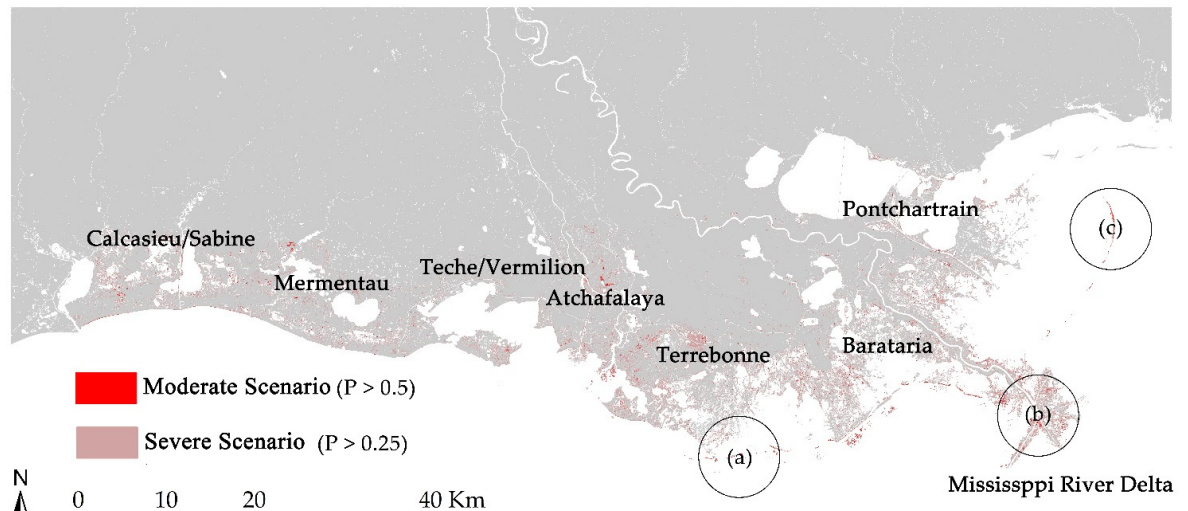

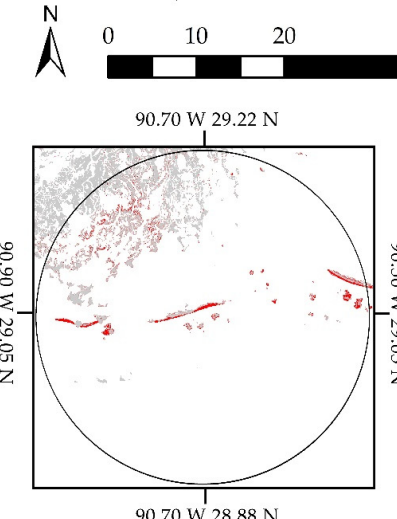

(a)

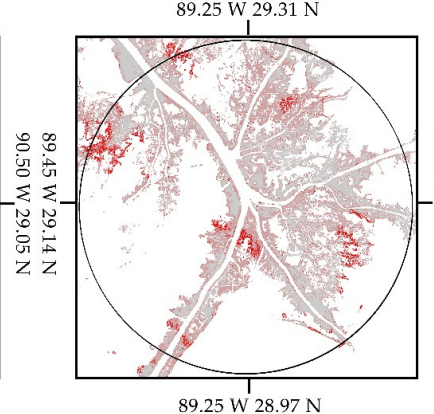

(b)

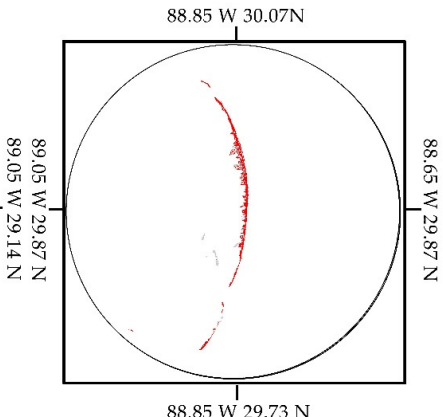

(c)

Figure 9. Simulated land loss patterns in LCZ from 2016 to 2031 under moderate and severe scenarios. (a) Timbalier Island in Terrebonne Basin. (b) Mississippi River Delta Basin. (c) Breton National Wildlife Refuge in Pontchartrain Basin. 


\section{Discussion and Conclusions}

This article investigated the spatial and temporal patterns of land loss in LCZ and analyzed the short-term and long-term land loss drivers and mechanisms. The objectives are threefold: (1) to examine the land loss patterns in LCZ from 2001 to 2016, (2) to quantify the land loss predictors in different periods, and (3) to simulate the future land loss. LR, XGBoost, and RF models were trained to understand the compounding effects of multicategory variables on the land loss process in LCZ. Finally, we simulated the land loss probability in LCZ from 2016 to 2031. The study demonstrated that overall land loss in LCZ decelerated since 2006 with more land gain than land loss along the Louisiana coastline. However, land loss/gain rate varies in different areas. Compared to the Mississippi River Delta, which experienced a significant land gain since 2006, there was an increasing land loss risk in western LCZ. The performance of XGBoost and RF models is better than that of LR models in both short- and long-term land loss modeling. The optimal land loss model is the long-term RF model in 2001-2016 with an F1-score of 0.82. Both the XGBoost and RF models reveal that oil/gas well density, subsidence rate, distance to urban and water areas, and Moran's I had constant high impacts on the short- and long-term land loss in coastal Louisiana during 2001-2016. The simulation result shows that a total of $173 \mathrm{~km}^{2}$ areas have an over $50 \%$ of land loss probability in 2016-2031.

This study generates valuable knowledge about the land loss crisis in coastal Louisiana. Contrary to the previous land loss simulations, which projected around $5000 \mathrm{~km}^{2}$ land loss over the next 50 years $[1,13,51]$, our results demonstrate that there were more land gains than land losses in recent years along the Louisiana coastline, especially since 2006. Simulation results further indicate that no more than $200 \mathrm{~km}^{2}$ of land will become water in LCZ during 2016-2031. This trend is confirmed in the latest 2019 LULC data obtained from the NLCD. We calculated the land loss areas and annual rates during 2016-2019 and compared them with the previous three 5-year periods (Figure 10). The yearly land loss speed in 2016-2019 was slower than the rates in 2001-2006 and 2006-2011, and greater than the speed in 2011-2016. The following reasons could explain the decelerated land loss in LCZ. First, because of recent land protection and restoration activities, the land loss rate was slowed down [15]. Second, natural disasters such as Hurricanes Katrina (2005) and Isaac (2012) might play a beneficial role in coastal wetland restoration by delivering more sediments to coastal regions that raise soil elevations and stimulate organic matter production [52].

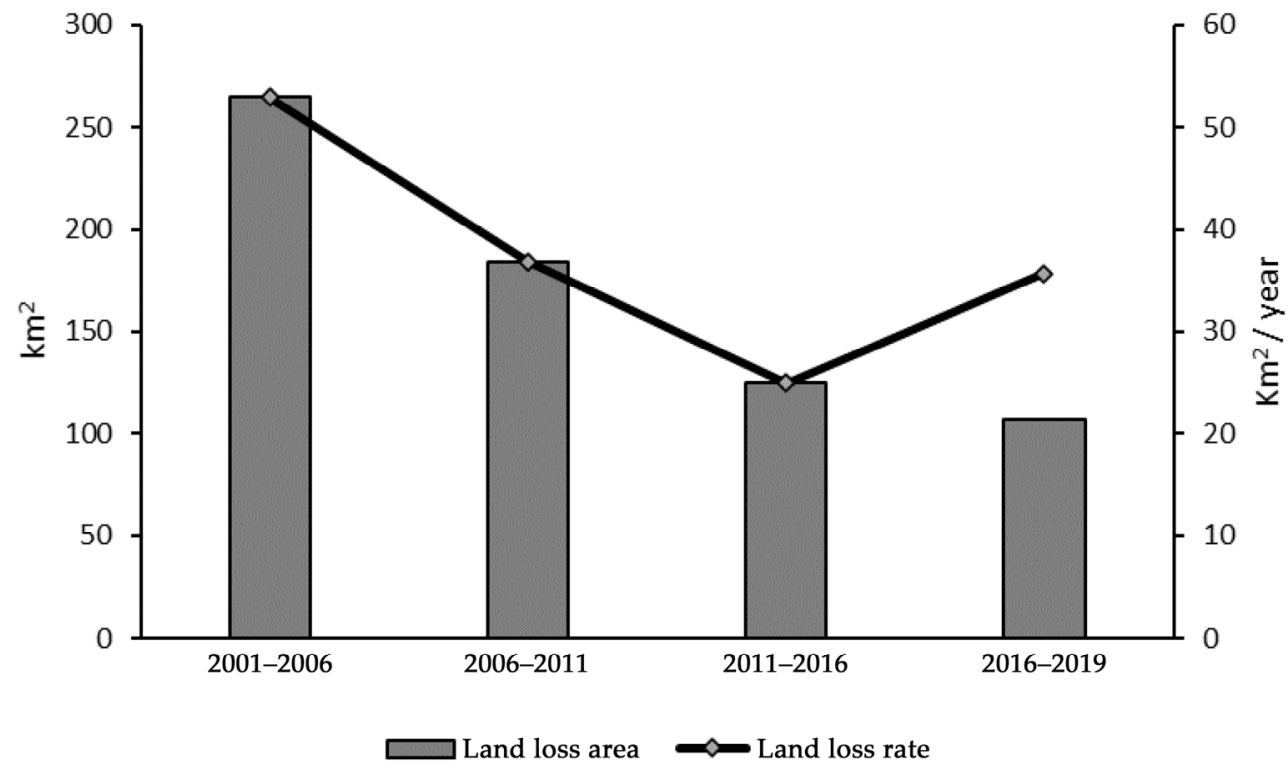

Figure 10. Land loss area in coastal Louisiana based on the latest 2019 LULC data. 
According to the LR result in different periods, elevation, the distance to water, and the neighborhood effect of urban cells have adverse impacts on the land loss in LCZ. This result is reasonable because land erosion tends to occur in areas with a lower altitude and that are closer to water. The neighborhood effect of urban cells has physical resistance to land loss and plays a beneficial role in land gain because of urbanization $[53,54]$. The neighborhood effects of other land cover types, including barren, water, vegetation, and agriculture cells, positively affect the land loss process in LCZ. The subsidence rate, Moran's I, and oil/gas well density have a positive effect on LCZ land loss. Based on RF and XGBoost models in different periods, oil/gas well density, subsidence rate, distance to water and urban areas, and Moran's I are the most significant features predicting the land loss process.

In addition to providing local knowledge for decision-makers and communities in coastal Louisiana, this research also offers valuable insights on (1) approaches to incorporate human impacts in environmental modeling, (2) a framework to analyze, model, and simulate LULC changes, and (3) performance evaluations of different regression and machine learning algorithms in land loss modeling, which could benefit large-scale (e.g., national or global) studies. Researchers could utilize this work to identify critical land loss drivers, select and customize machine learning algorithms, and simulate land loss or other landscape dynamics at a larger scale.

While this study has successfully revealed the short- and long-term spatial dynamics of land loss in LCZ and predicted its future land loss pattern to inform land restoration planning, there are several limitations that require further investigation. First, some critical variables, e.g., subsidence rates and elevations, were not updated in the modeling because datasets documenting those variables in different years are unavailable. This limitation can be resolved by developing physical or data-driven models of the critical variables and using the modeled variables in different years to simulate the land loss process. Second, uncertainties in the LULC data exist due to the image classification uncertainty [31], which might influence the modeling results. Multi-source data, such as LiDAR data, more sampling data, and high-resolution remote sensing data could be applied in future research to generate more accurate and reliable LULC data products. Third, the current land loss model does not consider different sea-level rise or climate change scenarios and might underestimate future land changes. Fourth, this study categorized the study area into land loss and no land loss classes and overlooked the land gain in modeling and simulations. Further studies could include both land loss and land gain processes in analyzing coastal land cover change. Finally, other machine learning models, such as artificial neural networks and deep learning, could be included to determine the optimal model for land loss predictions in future research.

Author Contributions: Conceptualization, L.Z. and M.Y.; methodology, M.Y. and L.Z.; validation, L.Z.; formal analysis, M.Y.; investigation, M.Y.; resources, L.Z. and M.Y.; data curation, M.Y.; writingoriginal draft preparation, M.Y. and L.Z.; writing-review and editing, L.Z., H.C., Y.Q., B.L., B.Z., J.A. and D.M.; visualization, M.Y.; supervision, L.Z. All authors have read and agreed to the published version of the manuscript.

Funding: This research received no external funding.

Data Availability Statement: Land use and land cover data are available on Multi-Resolution Land Characteristics Consortium website (https:/ / www.mrlc.gov/data, accessed on 15 November 2021). Elevation data are available on US Geological Survey (https: / / earthexplorer.usgs.gov /, accessed on 15 November 2021). Road data are available on US Census Bureau (https:/ / www.census.gov/, accessed on 15 November 2021). Soil data are available on the Digital General Soil Map of the United States (https: / / www.nrcs.usda.gov/, accessed on 15 November 2021). Subsidence rate data are available on NOAA's National Geodetic Survey (https:/ / geodesy.noaa.gov/, accessed on 15 November 2021).

Conflicts of Interest: The authors declare no conflict of interest. 


\section{References}

1. Reed, D.; Wang, Y.; Meselhe, E.; White, E. Modeling wetland transitions and loss in coastal Louisiana under scenarios of future relative sea-level rise. Geomorphology 2019, 352, 106991. [CrossRef]

2. Palaseanu-Lovejoy, M.; Kranenburg, C.; Barras, J.A.; Brock, J.C. Land Loss Due to Recent Hurricanes in Coastal Louisiana, USA. J. Coast. Res. 2013, 63, 97-109. [CrossRef]

3. O'Leary, M.; Gottardi, R. Relationship between Growth Faults, Subsidence, and Land Loss: An Example from Cameron Parish, Southwestern Louisiana, USA. J. Coast. Res. 2020, 36, 812. [CrossRef]

4. Mentaschi, L.; Vousdoukas, M.I.; Pekel, J.F.; Voukouvalas, E.; Feyen, L. Global long-term observations of coastal erosion and accretion. Sci. Rep. 2018, 8, 12876. [CrossRef]

5. Barbier, E.B.; Georgiou, I.Y.; Enchelmeyer, B.; Reed, D.J. The Value of Wetlands in Protecting Southeast Louisiana from Hurricane Storm Surges. PLoS ONE 2013, 8, e58715. [CrossRef]

6. Steyer, G.; Visser, J.; Owens, A.; Twilley, R. Coastal Louisiana Ecosystem Assessment and Restoration Program: The Role of Ecosystem Forecasting in Evaluating Restoration Planning in the Mississippi River Deltaic Plain. Trans. Am. Fish. Soc. 2008, 64, $29-46$.

7. Visser, J.M.; Duke-Sylvester, S.M.; Carter, J.; Broussard, W. A Computer Model to Forecast Wetland Vegetation Changes Resulting from Restoration and Protection in Coastal Louisiana. J. Coast. Res. 2013, 67, 51-59. [CrossRef]

8. Colten, C.E. Environmental management in coastal Louisiana: A historical review. J. Coast. Res. 2017, 33, 699-711.

9. Haer, T.; Kalnay, E.; Kearney, M.; Moll, H. Relative sea-level rise and the conterminous United States: Consequences of potential land inundation in terms of population at risk and GDP loss. Glob. Environ. Chang. 2013, 23, 1627-1636. [CrossRef]

10. Hemmerling, S.; Carruthers, T.; Hijuelos, A.; Bienn, H. Double exposure and dynamic vulnerability: Assessing economic well-being, ecological change and the development of the oil and gas industry in coastal Louisiana. Shore Beach 2020, 72-82. [CrossRef]

11. Tibbetts, J. Louisiana's Wetlands: A Lesson in Nature Appreciation. Environ. Health Perspect. 2006, 114. [CrossRef]

12. Roy, S.; Robeson, S.M.; Ortiz, A.C.; Edmonds, D.A. Spatial and temporal patterns of land loss in the Lower Mississippi River Delta from 1983 to 2016. Remote Sens. Environ. 2020, 250, 112046. [CrossRef]

13. Coastal Protection and Restoration Authority of Louisiana. 2017. Louisiana's Comprehensive Master Plan for a Sustainable Coast. Available online: http:/ / coastal.la.gov/wp-content/uploads/2017/04/2017-Coastal-Master-Plan_Web-Book_CFinalwith-Effective-Date-06092017.pdf (accessed on 15 November 2021).

14. Couvillion, B.R.; Beck, H.; Schoolmaster, D.; Fischer, M. Land area change in coastal Louisiana (1932 to 2016). U.S. Geol. Surv. 2017, 3381, 16. [CrossRef]

15. Killebrew, C.J.; Khalil, S.M. An overview of history of coastal restoration plans and programs in Louisiana. Shore Beach 2018, 86, 28-37.

16. Colten, C.E. Cartographic Depictions of Louisiana Land Loss: A Tool for Sustainable Policies. Sustainability 2018, $10,763$. [CrossRef]

17. Qiang, Y.; Lam, N.S.N. Modeling land use and land cover changes in a vulnerable coastal region using artificial neural networks and cellular automata. Environ. Monit. Assess. 2015, 187, 57. [CrossRef] [PubMed]

18. Zou, L.; Kent, J.; Lam, N.S.N.; Cai, H.; Qiang, Y.; Li, K. Evaluating Land Subsidence Rates and Their Implications for Land Loss in the Lower Mississippi River Basin. Water 2015, 8, 10. [CrossRef]

19. Glick, P.; Clough, J.; Polaczyk, A.; Couvillion, B.; Nunley, B. Potential Effects of Sea-Level Rise on Coastal Wetlands in Southeastern Louisiana. J. Coast. Res. 2013, 63, 211-233. [CrossRef]

20. Olea, R.A.; Coleman, J.L., Jr. A synoptic examination of causes of land loss in southern Louisiana as related to the exploitation of subsurface geologic resources. J. Coast. Res. 2014, 30, 1025-1044. [CrossRef]

21. Lam, N.S.N.; Cheng, W.; Zou, L.; Cai, H. Effects of landscape fragmentation on land loss. Remote Sens. Environ. 2018, $209,253-262$. [CrossRef]

22. Altinay, Z.; Rittmeyer, E.; Morris, L.L.; Reams, M.A. Public risk salience of sea level rise in Louisiana, United States. J. Environ. Stud. Sci. 2020, 11, 523-536. [CrossRef]

23. Day, J.W.; Templet, P. Consequences of sea level rise: Implications from the Mississippi Delta. Coast. Manag. 1989, 17, $241-257$. [CrossRef]

24. FitzGerald, D.; Kulp, M.; Hughes, Z.; Georgiou, I.; Miner, M.; Penland, S.; Howes, N. Impacts of Rising Sea Level to Backbarrier Wetlands, Tidal Inlets, and Barrier Islands: Barataria Coast, Louisiana. Proc. Coast. Sediments 2007, 7, 1179-1192. [CrossRef]

25. Jankowski, K.L.; Törnqvist, T.E.; Fernandes, A.M. Vulnerability of Louisiana's coastal wetlands to present-day rates of relative sea-level rise. Nat. Commun. 2017, 8, 14792. [CrossRef]

26. Day, J.W.; Shaffer, G.P.; Cahoon, D.R.; De Laune, R.D. Canals, backfilling and wetland loss in the Mississippi Delta. Estuarine Coast. Shelf Sci. 2019, 227, 106325. [CrossRef]

27. Cahoon, D.R.; Lynch, J.C.; Roman, C.T.; Schmit, J.P.; Skidds, D.E. Evaluating the Relationship Among Wetland Vertical Development, Elevation Capital, Sea-Level Rise, and Tidal Marsh Sustainability. Estuaries Coasts 2018, 42, 1-15. [CrossRef]

28. Jin, S.; Homer, C.; Yang, L.; Danielson, P.; Dewitz, J.; Li, C.; Zhu, Z.; Xian, G.; Howard, D. Overall Methodology Design for the United States National Land Cover Database 2016 Products. Remote Sens. 2019, 11, 2971. [CrossRef] 
29. Choi, W.; Deal, B.M. Assessing hydrological impact of potential land use change through hydrological and land use change modeling for the Kishwaukee River basin (USA). J. Environ. Manag. 2008, 88, 1119-1130. [CrossRef]

30. Hu, T.; Liu, J.; Zheng, G.; Zhang, D.; Huang, K. Evaluation of historical and future wetland degradation using remote sensing imagery and land use modeling. Land Degrad. Dev. 2019, 31, 65-80. [CrossRef]

31. Wickham, J.; Stehman, S.V.; Homer, C.G. Spatial patterns of the United States National Land Cover Dataset (NLCD) land-cover change thematic accuracy (2001-2011). Int. J. Remote Sens. 2017, 39, 1729-1743. [CrossRef]

32. Anderson, J.R.; Hardy, E.E.; Roach, J.T.; Witmer, R.E. A Land Use and Land Cover Classification System for Use with Remote Sensor Data; Geological Survey Professional Paper 964; United States Department of the Interior: Washington, DC, USA, 1976.

33. Ortiz, A.C.; Roy, S.; Edmonds, D.A. Land loss by pond expansion on the Mississippi River Delta Plain. Geophys. Res. Lett. 2017, 44, 3635-3642. [CrossRef]

34. Day, J.W., Jr.; Boesch, D.F.; Clairain, E.J.; Kemp, G.P.; Laska, S.B.; Mitsch, W.J.; Orth, K.; Mashriqui, H.; Reed, D.J.; Shabman, L.; et al. Restoration of the Mississippi Delta: Lessons from Hurricanes Katrina and Rita. Science 2007, 315, 1679-1684. [CrossRef]

35. Chambers, L.G.; Steinmuller, H.E.; Breithaupt, J.L. Toward a mechanistic understanding of "peat collapse" and its potential contribution to coastal wetland loss. Ecology 2019, 100, e02720. [CrossRef]

36. Scavia, D.; Field, J.C.; Boesch, D.F.; Buddemeier, R.W.; Burkett, V.; Cayan, D.R.; Fogarty, M.; Harwell, M.A.; Howarth, R.; Mason, C.; et al. Climate change impacts on U.S. Coastal and Marine Ecosystems. Estuaries 2002, 25, 149-164. [CrossRef]

37. González, J.L.; Tornqvist, T.E. Coastal Louisiana in crisis: Subsidence or sea level rise? Eos Trans. Am. Geophys. Union 2006, 87, 493-498. [CrossRef]

38. Overmars, K.; de Koning, G.; Veldkamp, T. Spatial autocorrelation in multi-scale land use models. Ecol. Model. 2003, 164, 257-270. [CrossRef]

39. Wear, D.N.; Bolstad, P. Land-use changes in southern Appalachian landscapes: Spatial analysis and forecast evaluation. Ecosystems 1998, 1, 575-594. [CrossRef]

40. Bi, X.; Wang, B.; Lu, Q. Fragmentation effects of oil wells and roads on the Yellow River Delta, North China. Ocean Coast. Manag. 2011, 54, 256-264. [CrossRef]

41. Feng, Y.; Liu, Y. A heuristic cellular automata approach for modelling urban land-use change based on simulated annealing. Int. J. Geogr. Inf. Sci. 2013, 27, 449-466. [CrossRef]

42. Cowan, J.H., Jr.; Turner, R.E. Modeling wetland loss in coastal Louisiana: Geology, geography, and human modifications. Environ. Manag. 1988, 12, 827-838. [CrossRef]

43. Rahman, H.A.A.; Wah, Y.B.; He, H.; Bulgiba, A. Comparisons of ADABOOST, KNN, SVM and Logistic Regression in Classification of Imbalanced Dataset; Springer: Singapore, 2015; pp. 54-64. [CrossRef]

44. Cai, H.; Lam, N.S.N.; Zou, L.; Qiang, Y. Modeling the Dynamics of Community Resilience to Coastal Hazards Using a Bayesian Network. Ann. Am. Assoc. Geogr. 2018, 108, 1260-1279. [CrossRef]

45. Breiman, L. Random forests. Mach. Learn. 2001, 45, 5-32. [CrossRef]

46. Kamusoko, C.; Gamba, J. Simulating Urban Growth Using a Random Forest-Cellular Automata (RF-CA) Model. ISPRS Int. J. Geo-Inf. 2015, 4, 447-470. [CrossRef]

47. Liaw, A.; Wiener, M. Classification and regression by RandomForest. R News 2002, 2, 18-22.

48. Chen, T.; Guestrin, C. Xgboost: A scalable tree boosting system. In Proceedings of the 22nd ACM SIGKDD International Conference on Knowledge Discovery and Data Mining, San Francisco, CA, USA, 13-17 August 2016.

49. Fan, J.; Upadhye, S.; Worster, A. Understanding receiver operating characteristic (ROC) curves. Can. J. Emerg. Med. 2006, 8, 19-20. [CrossRef] [PubMed]

50. Goutte, C.; Gaussier, E. A probabilistic interpretation of precision, recall and F-score, with implication for evaluation. In European Conference on Information Retrieval; Springer: Berlin, Germany, 2005; pp. 345-359.

51. Barras, J.; Beville, S.; Britsch, D.; Hartley, S.; Hawes, S.; Johnston, J.; Kemp, P.; Kinler, Q.; Martucci, A.; Porthouse, J.; et al. Historical and Projected Coastal Louisiana Land Changes: 1978-2050; United States Geological Survey Open File Report: Reston, VA, USA, 2003.

52. McKee, K.L.; Cherry, J.A. Hurricane Katrina sediment slowed elevation loss in subsiding brackish marshes of the Mississippi River delta. Wetlands 2009, 29, 2-15. [CrossRef]

53. Boyer, T.; Polasky, S. Valuing urban wetlands: A review of non-market valuation studies. Wetlands 2004, 24, 744-755. [CrossRef]

54. Rojas, C.; Munizaga, J.; Rojas, O.; Martínez, C.; Pino, J. Urban development versus wetland loss in a coastal Latin American city: Lessons for sustainable land use planning. Land Use Policy 2018, 80, 47-56. [CrossRef] 